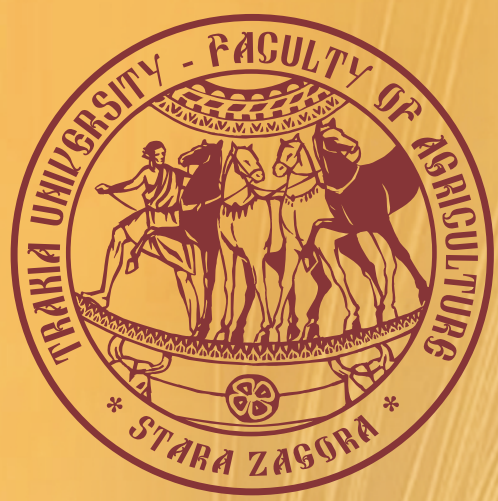

ISSN $1313-8820$ (print)

ISSN 1314 - 412X (online)

Volume 9 , Number 4

December 2017

\title{
AGRICULTURAL
}

\section{SCIENCE AND TECHNOLOGY}

\section{7}

An International Journal Published by Faculty of Agriculture, Trakia University, Stara Zagora, Bulgaria 


\section{Editor-in-Chief}

Georgi Petkov

Faculty of Agriculture

Trakia University, Stara Zagora

Bulgaria

E-mail: gpetkov@af.uni.sz.bg

\section{Co-Editor-in-Chief}

Dimitar Panayotov

Faculty of Agriculture

Trakia University, Stara Zagora

Bulgaria

\section{Editors and Sections}

\section{Genetics and Breeding}

Tsanko Yablanski (Bulgaria)

Atanas Atanasov (Bulgaria)

Svetlana Georgieva (Bulgaria)

Nikolay Tsenov (Bulgaria)

Max Rothschild (USA)

Ihsan Soysal (Turkey)

Horia Grosu (Romania)

Stoicho Metodiev (Bulgaria)

Bojin Bojinov (Bulgaria)

\section{Nutrition and Physiology}

Nikolai Todorov (Bulgaria)

Peter Surai (UK)

Ivan Varlyakov (Bulgaria)

George Zervas (Greece)

Vasil Pirgozliev (UK)

\section{Production Systems}

Radoslav Slavov (Bulgaria)

Dimitar Pavlov (Bulgaria)

Bogdan Szostak (Poland)

Banko Banev (Bulgaria)

Georgy Zhelyazkov (Bulgaria)

\section{Agriculture and Environment}

Martin Banov (Bulgaria)

Peter Cornish (Australia)

Vladislav Popov (Bulgaria)

Tarek Moussa (Egypt)

\section{Product Quality and Safety}

Stefan Denev (Bulgaria)

Vasil Atanasov (Bulgaria)

Roumiana Tsenkova (Japan)

\section{English Editor}

Yanka Ivanova (Bulgaria)
Scope and policy of the journal

Agricultural Science and Technology /AST/

- an International Scientific Journal of Agricultural and Technology Sciences is published in English in one volume of 4 issues per year, as a printed journal and in electronic form. The policy of the journal is to publish original papers, reviews and short communications covering the aspects of agriculture related with life sciences and modern technologies. It will offer opportunities to address the global needs relating to food and environment, health, exploit the technology to provide innovative products and sustainable development. Papers will be considered in aspects of both fundamental and applied science in the areas of Genetics and Breeding, Nutrition and Physiology, Production Systems, Agriculture and Environment and Product Quality and Safety. Other categories closely related to the above topics could be considered by the editors. The detailed information of the journal is available at the website. Proceedings of scientific meetings and conference reports will be considered for special issues.

\section{Submission of Manuscripts}

There are no submission / handling / publication charges.

All manuscripts written in English should be submitted as MS-Word file attachments via e-mail to editoffice@agriscitech.eu. Manuscripts must be prepared strictly in accordance with the detailed instructions for authors at the website

www.agriscitech.eu and the instructions on the last page of the journal. For each manuscript the signatures of all authors are needed confirming their consent to publish it and to nominate on author for correspondence.

They have to be presented by a submission letter signed by all authors. The form of the submission letter is available upon from request from the Technical Assistance or could be downloaded from the website of the journal. Manuscripts submitted to this journal are considered if they have submitted only to it, they have not been published already, nor are they under consideration for publication in press elsewhere. All manuscripts are subject to editorial review and the editors reserve the right to improve style and return the paper for rewriting to the authors, if necessary. The editorial board reserves rights to reject manuscripts based on priorities and space availability in the journal.

The journal is committed to respect high standards of ethics in the editing and reviewing process and malpractice statement. Commitments of authors related to authorship are also very important for a high standard of ethics and publishing. We follow closely the Committee on Publication Ethics (COPE), http://publicationethics.org/resources/guid elines

The articles appearing in this journal are indexed and abstracted in: DOI, EBSCO Publishing Inc., AGRIS (FAO) and DOAJ.

The journal is accepted to be indexed with the support of a project № BG051P00013.3.05-0001 "Science and business" financed by Operational Programme "Human Resources Development" of EU. The title has been suggested to be included in SCOPUS (Elsevier) and Electronic Journals Submission Form (Thomson Reuters).

The journal is freely available without charge to the user or his/her institution. Users can read, download, copy, distribute, print, search, or link to the full texts of the articles, or use them for any other lawful purpose, without asking prior permission from the publisher or the author.

This issue is printed with the financial support by Contract No DNP 0521/20.12.2016, financed from Fund 'Scientific Research' grant Bulgarian scientific Periodicals.

\section{Address of Editorial office:}

Agricultural Science and Technology Faculty of Agriculture, Trakia University

Student's campus, 6000 Stara Zagora

Bulgaria

Telephone: +35942699330 $+35942699446$

www.agriscitech.eu

Technical Assistance:

Nely Tsvetanova

Telephone: +359 42699446

E-mail:editoffice@agriscitech.eu 


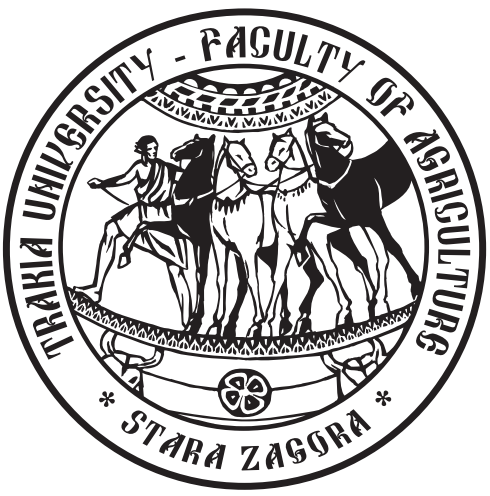

AGRICULTURAL

SCIENCE AND TECHNOLOGY

\section{7}

An International Journal Published by Faculty of Agriculture,

Trakia University, Stara Zagora, Bulgaria 


\title{
Taxonomic composition of phytoplankton in Black Sea area in front of the Cape Galata (2008- 2016)
}

\author{
D. Klisarova*, D. Gerdzhikov \\ Institute of Fish Resources, 9000 Varna, Bulgaria \\ (Manuscript received 13 August 2017; accepted for publication 3 October 2017)
}

Abstract. In this article have been investigated the taxonomic structure of the phytoplankton communities developing in the Black Sea area in front of the Cape Galata. For the period 2008 - 2016, relatively high species diversity was found (161 species). Throughout the most of the year dominated class Dinophyceae (up to $54.17 \%$ ). The number of phytoplankton species decreased with distance from the shore, but the percentage participation of the group of peridineas and diatoms in the general taxonomic composition grew. Only in class Prymnesiophyceae increased biodiversity was registered in the high seas.

Keywords: Black Sea, cape Galata, phytoplankton, biodiversity, dynamic

\section{Introduction}

For Black Sea water in front of cape Galata multiannual monitoring data of phytoplankton taxonomic structure is available, starting from 1954. This feature is important in tracking current changes occurring in the Black Sea ecosystem (Petrova and Gerdzhikov, 2012). The analyzed water area is considered to be sufficiently representative for ecological assessments of the Bulgarian marine water areas (Moncheva and Slabakova, 2013).

The first ecological studies on phytoplankton in front of cape Galata have been published by Petrova $(1963,1964,1965,1966)$ and Petrova-Karadjova (1973). They include the seasonal composition of the dominant phytoplankton complexes in the area.

A full floristic list of the marine phytoplankton in front of the Bulgarian Black Sea coast (including the water area in front of cape Galata) was published in 1998, where 255 species, 10 varieties and forms from 97 families belonging to 8 phyla (Petrova-Karadjova and Moncheva, 1998) were reported. In 2005, 302 species, varieties and forms of phytoplankton were reported in the Bulgarian marine areas, among them Dinophyceae prevailing with $41.7 \%$, followed by Bacillariophycea with $36.4 \%$ (Temniskova et al., 2005). In 2010, the presence of 600 phytoplankton species in the Bulgarian marine area was established (Moncheva, 2010). During the period 2006-2011, development of 319 species from 10 classes (Moncheva et al., 2013) was found during sampling at cape Galata with designated assessment areas (coastal zone, shelf and open sea).

The aim of the present study was to establish the peculiarities of the phytoplankton taxonomic composition in Black Sea marine water area in front of cape Galata. The study is a contribution to the modern biodiversity assessment using BQE (Biological Quality Element) phytoplankton for selected stations from the national monitoring scheme.

\section{Material and methods}

The study was carried out within the period 2008-2016, during *e-mail: danielaklisarova1@abv.bg the months of March to December, by transect Galata (Black Sea, BS) (up to 20 nautical miles off shore). The scientific expeditions were conducted on board the research vessel Prof. Al. Valkanov and others vessels. Phytoplankton samples (157) were collected from 4 stations as follow:

- Galata 1 nautical mile (nm), (G-1): 43.16795; 27.96866;

- Galata 3 nm (G-3): 43.16124;28.01305;

- Galata $10 \mathrm{~nm}(\mathrm{G}-10): 43.13769 ; 28.16914$;

- Galata $20 \mathrm{~nm}(\mathrm{G}-20): 43.10367 ; 28.3919$;

at standard horizons $(0,10,25,50 \mathrm{~m})$ and one meter above the bottom by bathometers type Niskin-5L (Figure 1).

The samples were fixed onboard the ship in $2 \%$ formalin solution and concentrated by the sedimentary method (MorozovaVodyanitskaya, 1954). The qualitative and quantitative analyses of the samples were performed with a light microscope Nikon E400 and OlympusBX41 in counting cells Sedgewick Rafter- $1 \mathrm{ml}$ and PalmerMaloney - $0.05 \mathrm{ml}$, using standard methods (Moncheva and Parr, 2010).

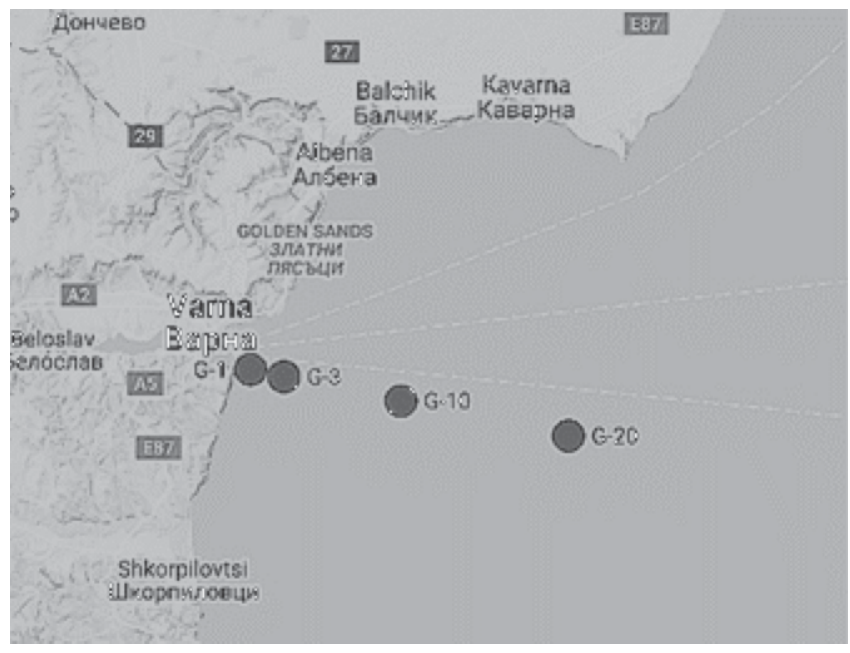

Figure 1. Map of sampling station locations 
When specifying the names of phyla and classes of phytoplankton species and taxa, besides the traditional identifiers for the Black Sea and the World Ocean (Nordisches Plankton, 1908; Lebour, 1925; Rabenhorsts, 1930; Schiller, 1931-1937; Zhuze et al., 1949ab; Kiselev, 1950; Zabelina et al., 1950; Proshkina-Lavrenko, 1955, 1959, 1963; Vodenicharov et al., 1971; Glezer et al., 1974) electronic sources of taxonomic information were also used, WoRMS (2016).

The taxonomic classification of phyla and classes was made according Temniskova and Stoyneva (2011) and WoRMS (2016).

\section{Results and discussion}

A total of 161 species and forms of phytoplankton microalgae from 84 genera, 62 families, 14 classes and 7 phyla were identified in the marine water area in front of cape Galata during the period 20082016 (Table 1-4, Figure 4).

The highest number of species (70 pcs, $43.48 \%$ ) exhibited class Dinophyceae (with 26 genera: Akashiwo, Alexandrium, Amphidinium, Cochlodinium, Dinophysis, Diplopsalis, Durinskia, Glenodinium, Gonyaulax, Gymnodinium, Gyrodinium,

Table 1. Taxonomic structure of phytoplankton in the transect Galata $1 \div 20$ miles, $2008-2016$

\begin{tabular}{lccccc}
\hline \hline \multicolumn{7}{c}{ Number taxa } \\
\hline Divisions & Class & Order & Family & Genus & Species \\
\hline Chlorophyta & 4 & 7 & 9 & 12 & 13 \\
Cryptophyta & 1 & 3 & 4 & 4 & 5 \\
Cyanoprokaryota & 1 & 3 & 4 & 5 & 5 \\
Euglenophyta & 1 & 2 & 3 & 4 & 7 \\
Haptophyta & 1 & 4 & 23 & 27 & 6 \\
Ochrophyta & 4 & 18 & 14 & 27 & 54 \\
Pyrophyta & 2 & 9 & 62 & 84 & 71 \\
Total & 14 & 46 & & & 161 \\
\hline \hline
\end{tabular}

Heterocapsa, Lessardia, Lingulodinium, Minuscula, Neoceratium, Oblea, Oxyrrhis, Peridinium, Polykrikos, Pronoctiluca, Prorocentrum, Protoceratium, Protoperidinium, Scrippsiella, Woloszynskia).

In the taxonomic group Dinoflagellata incertae sedis (by WoRMS, 2016) the species Hermesinum adriaticum O. Zacharias, 1906 was registered, with sizes ranging between $25 \div 45 \mu \mathrm{m}$ in length and $10 \div 25 \mu \mathrm{m}$ width $(0.62 \%)$ (Figure 2 ).

The second class, dominant in the number of phytoplankton species was Bacillariophyceae (50 species, 31.06\%) distributed in 23 genera (Achnanthes, Amphora, Cerataulina, Chaetoceros, Cocconeis, Coscinodiscus, Cyclotella, Dactyliosolen, Diatoma, Ditylum, Halamphora, Leptocylindrus, Navicula, Nitzschia, Paralia, Pleurosigma, Proboscia, Pseudo-nitzschia, Pseudosolenia, Skeletonema, Synedra, Thalassionema, Thalassiosira).

In the other classes of microalgae (the group of "other") with the

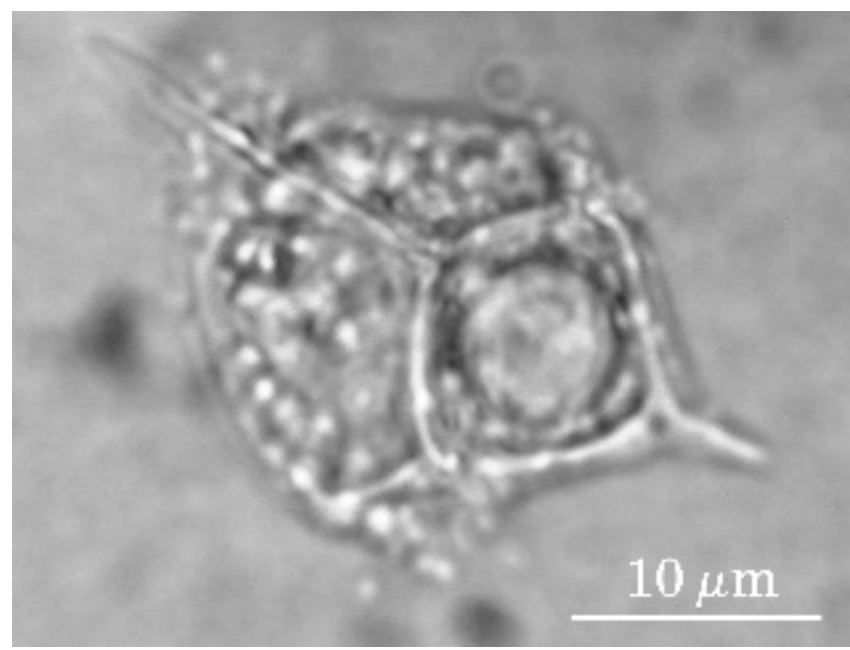

Figure 2. Microphotography of the species Hermesinum adriaticum from the Bulgarian marine waters highest share was the class Chlorophyceae (8 species, 4.97\%, in 6 genera) with genera Chlamydomonas, Golenkinia, Monoraphidium, Platymonas, Scenedesmus and Treubaria. To the group Chlorophyta incertae sedis $(0.62 \%)$ belongs one of the most common in our marine water Poropila dubia Schiller, 1925, with sizes ranging between $15 \div 45 \mu \mathrm{m}$ (Figure 3 ).

In class Euglenophyceae were registered a total of 7 species $(4.35 \%)$ distributed in 4 genera (Euglena, Eutreptia, Eutreptiella, Phacus). Class Prasinophyceae developed with 2 species (1.24\%) and genera Pachysphaera and Pyramimonas. In class Trebouxiophyceae were registerd 2 species (1.24\%) of genera Oocystis and Trochiscia.

The rare Dinobryon balticum (Schütt) Lemmermann, 1900

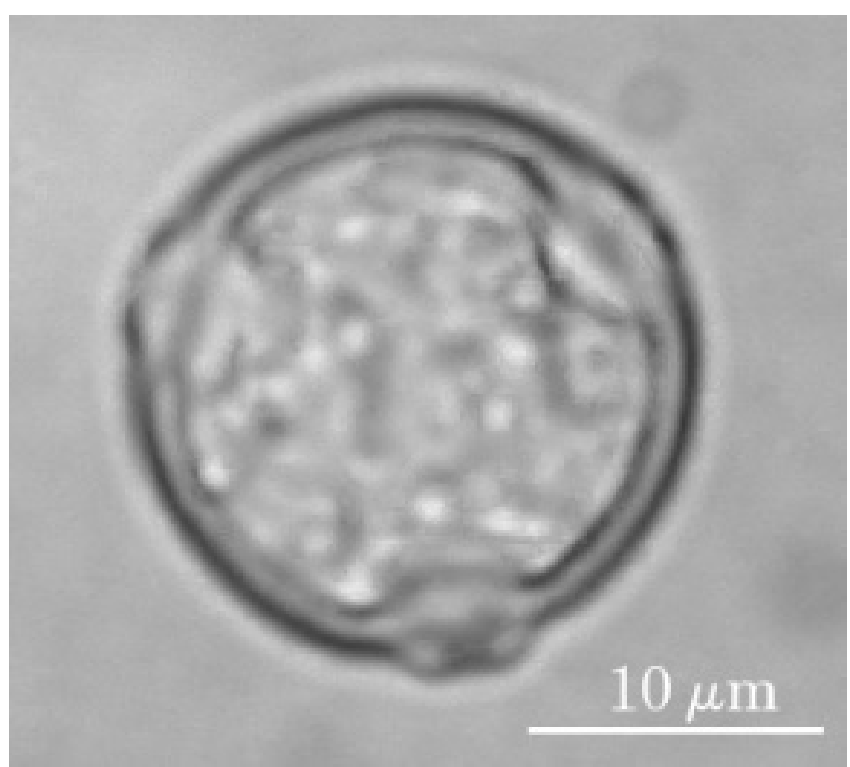

Figure 3. Microphotography of the phytoplankton species Poropila dubia from Bulgarian aquatories of Black Sea 
$(0.62 \%)$ from class Chrysophyceae was found. Class Dictyochophyceae with 2 species (1.24\%): Apedinella radians (Lohmann) Campbell, 1973 (syn. A.spinifera) and Distephanus speculum (Ehrenberg) Haeckel, 1887. Class Prymnesiophyceae with 6 species, $3.73 \%$ and 5 genera: Acanthoica, Coccolithus, Emiliania, Phaeocystis, Syracosphaera. Class Cryptophyceae with 5 species, $3.11 \%$ and 4 genera: Chroomonas, Cryptomonas, Leucocryptos and Rhodomonas, as well as several representatives of the small flagellates group - unidentified in genus and species by a light microscope cryptophytes.
Compared to the waters of Varna and Burgas bays (Klisarova et al., 2015a, 2015b), along transect Galata, class Cyanophyceae was presented with a few species (5 species, 3.11\%) and 4 genera Merismopedia, Oscillatoria, Phormidium, Spirulina. The reason is the weaker influence of coastal freshwater which enriches marine water with representatives of blue-green algae.

Class Craspedophyceae $(0.62 \%)$ was presented with one species - the relatively common but in low concentrations Bicosta spinifera Leadbeater, 1978) (Christensen, 1966; Hibberd, 1975) (Figure 4).

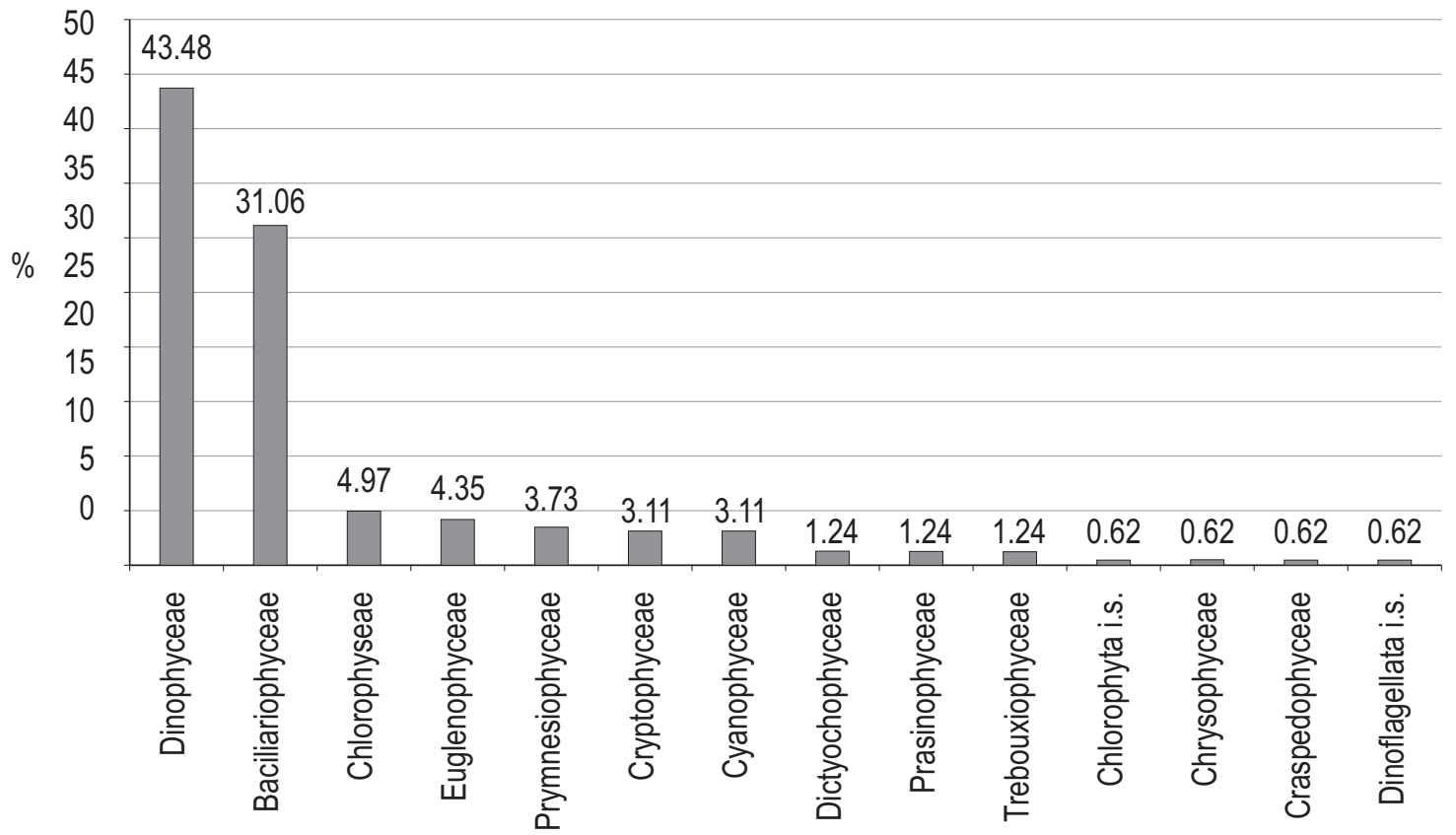

Figure 4. Percentage distribution of phytoplankton species by classes, transect Galata (2008-2016)

The group of diatoms and peridineas prevailed with $75.16 \%$ in the taxonomic composition of phytoplankton, while the group of "other" (all other microalgae) developed with $24.84 \%$ - a ratio close to "normal" for the marine environment.

The highest phytoplankton diversity was observed in spring and autumn with a peak in May (87 species), and in the second half of the year the maximum was in September (84) (Figure 5).

During the cold period from December to April, the species diversity was low (Figure 5). A decrease in the number of vegetative phytoplankton species is usually recorded in the winter (Petrova and

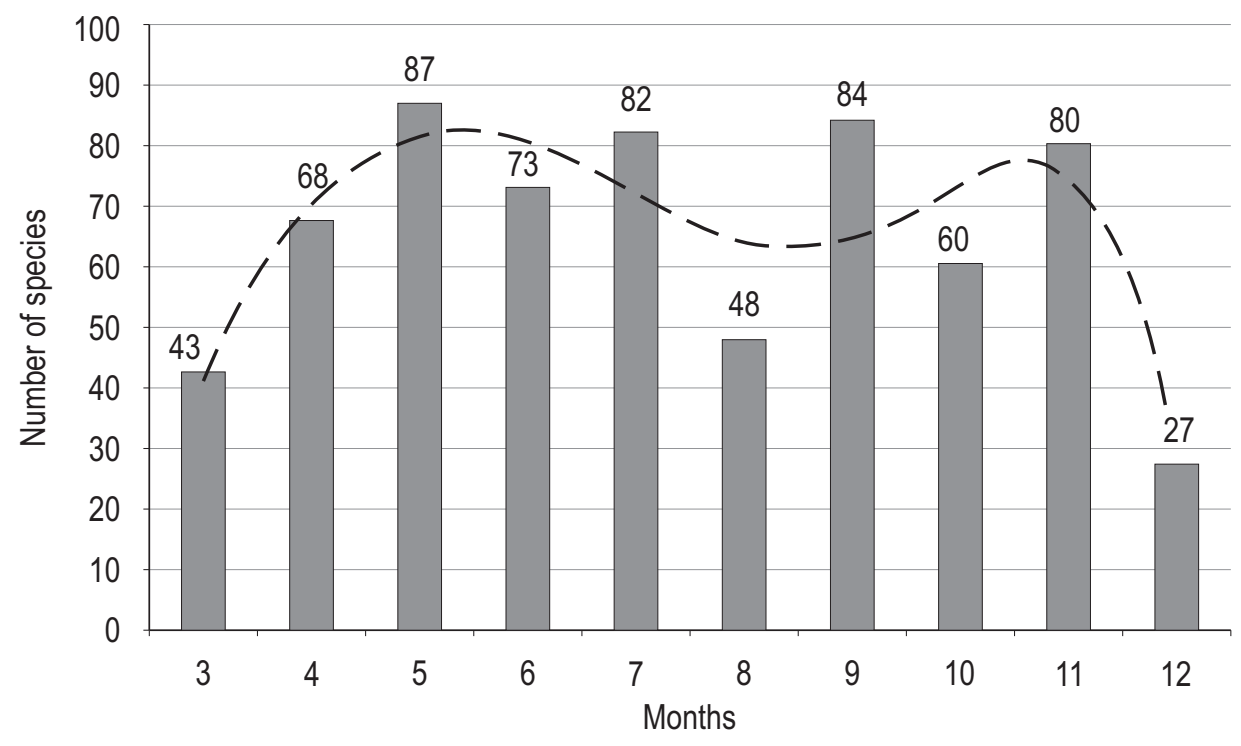

Figure 5. Dynamics of species diversity by months (polynomial trendline, order 6 ), transect Galata (2008-2016) 
Gerdzhikov, 2015). In the waters of Varna Bay, adjacent to Galata transect, in July and August was observed summer minimum in phytoplankton biodiversity, while the annual maximums were in June and September (Klisarova et al., 2015a).

In front of cape Galata such phenomenon was not registered. In summer, the smallest number of species was observed in August, and peaks in biodiversity were established in May, July, September and November (Figure 5).

Most likely, this difference between the two water areas is due to hydrographic peculiarities, influence of temperature regimes (Dineva, 2009, 2013). As a more open water area, the waters in front of cape Galata are subjected to intense impact of wind waves and currents causing disturbances in the successions of phytoplankton communities. In the pelagial, the most well-known disturbances are related to hydraulic or hydrographic impacts on the water column or to the periodicity of the supply of biogens (Sommer et al., 1993; Sommer, 1995) where the disturbance appeared as a response from the community to the external influence (Reynolds, 2006). Disturbance is a situation where short-term environmental changes lead to significant changes in the initial structure of the community that could not be recovered in a short term. The impact of disturbances on biodiversity is related to the intensity and especially to the frequency of the upcoming events (Polishchuk, 1999).

The seasonal dynamics of phytoplankton classes in the taxonomic structure is influenced by the temperature - in the warm months of the year (from April to August) class Dinophyceae was the most numerous one. Unlike Varna Bay (Klisarova et al., 2015a), in the waters in front of Galata, a maximum in the participation of the peridineas was also observed in November. The diatoms dominated only in October and December (Figure 6).

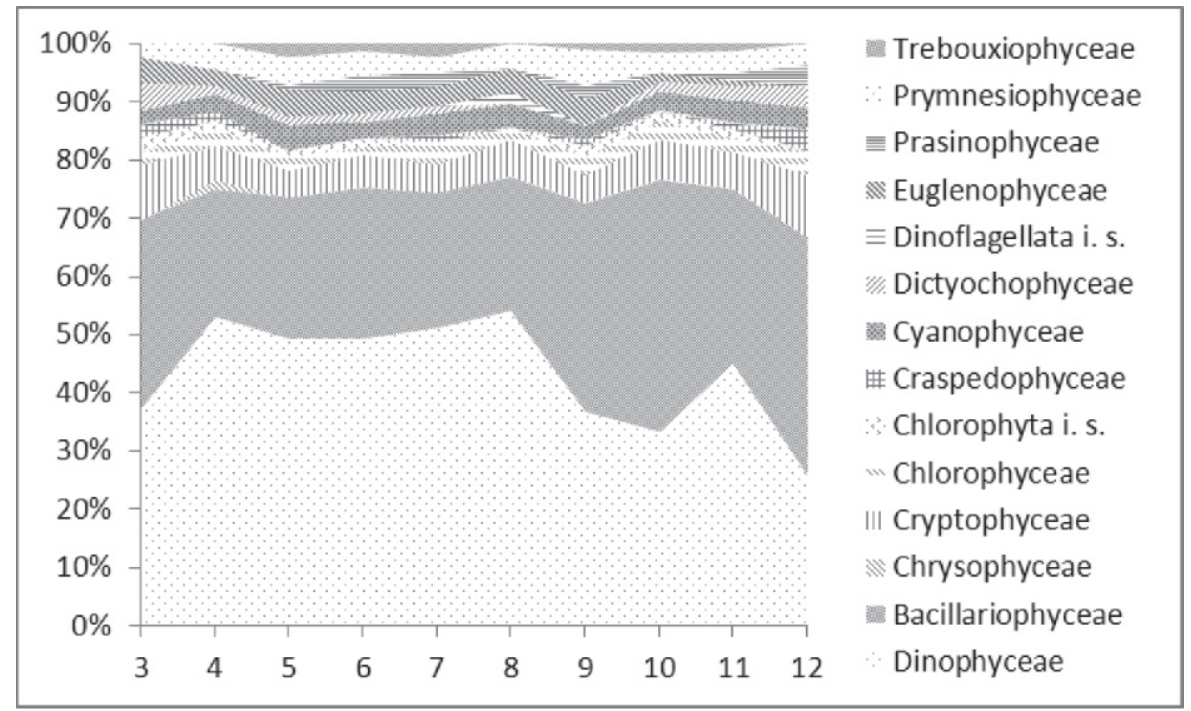

Figure 6. Monthly dynamics of the taxonomic structure of phytoplankton (by classes), transect Galata (2008-2016)

Table 2. Taxonomic structure of phytoplankton (number of species by classes) at the stations along Galata transect, 20082016

\begin{tabular}{|c|c|c|c|c|}
\hline Class / Station & Galata $1 \mathrm{~nm}$ & Galata $3 \mathrm{~nm}$ & Galata $10 \mathrm{~nm}$ & Galata $20 \mathrm{~nm}$ \\
\hline Dinophyceae & 62 & 48 & 36 & 19 \\
\hline Bacillariophyceae & 43 & 33 & 28 & 15 \\
\hline Chrysophyceae & - & - & 1 & - \\
\hline Cryptophyceae & 5 & 4 & 4 & 3 \\
\hline Chlorophyceae & 6 & 3 & 2 & 1 \\
\hline Chlorophyta i.s. & 1 & 1 & 1 & - \\
\hline Craspedophyceae & 1 & 1 & & \\
\hline Cyanophyceae & 5 & 3 & 2 & 2 \\
\hline Dictyochophyceae & 2 & 2 & - & - \\
\hline Dinoflagellata i.s. & 1 & - & - & - \\
\hline Euglenophyceae & 6 & 5 & - & 1 \\
\hline Prasinophyceae & 2 & 1 & 2 & - \\
\hline Prymnesiophyceae & 4 & 4 & 6 & 4 \\
\hline Trebouxiophyceae & 1 & 2 & 1 & - \\
\hline Total number of species & 139 & 107 & 83 & 45 \\
\hline
\end{tabular}




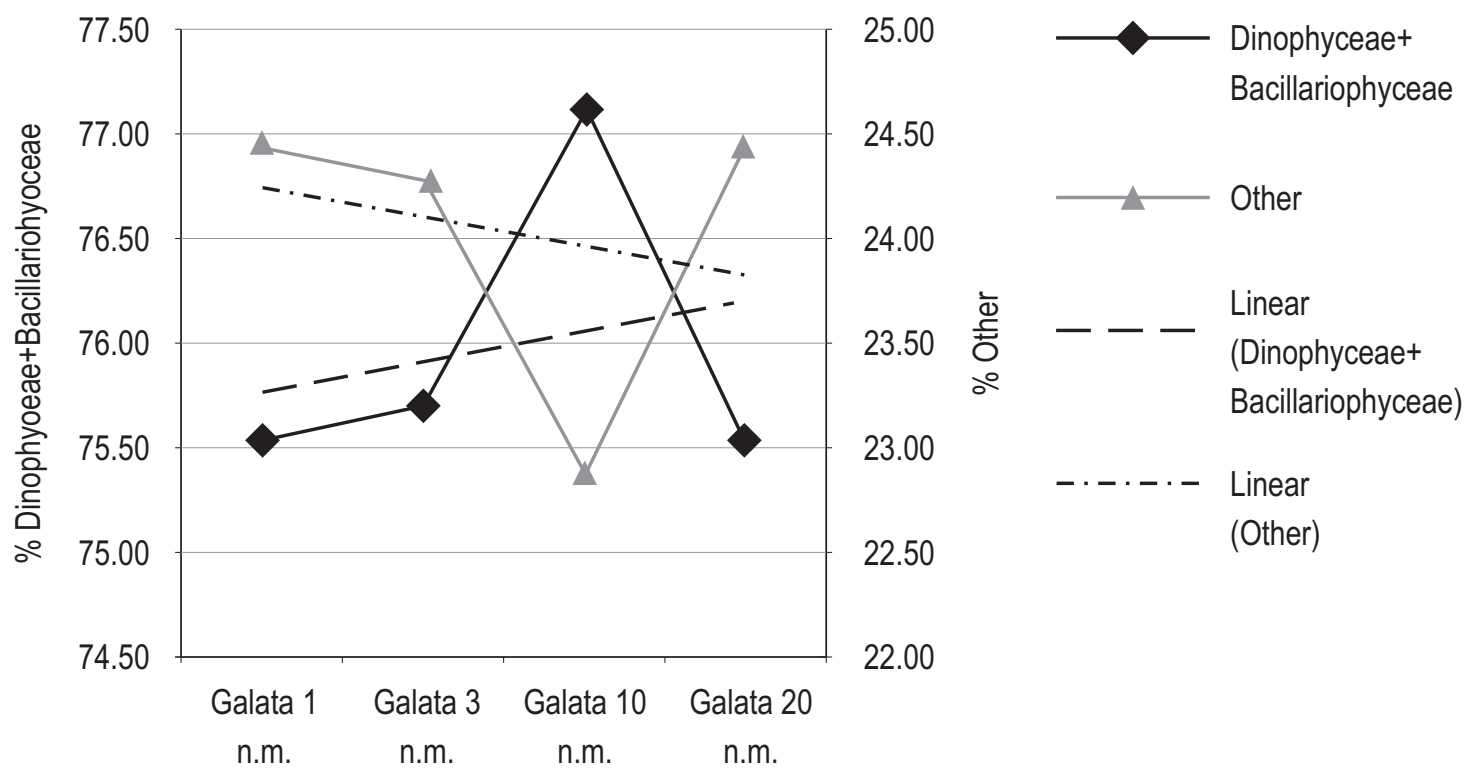

Figure 7. Dynamics of the percentage share of the main phytoplankton groups in the taxonomic composition along transect Galata, 2008-2016 (for comparison of the data with earlier studies (Nesterova et al., 2008), the percentages of Dinoflagellata incertae sedis are added to the group of Dinophyceae)

By moving away from the coast, the number of registered phytoplankton species decreased (Table 2) as the percentage share of the group Dinophyceae and Bacillariophyceae increased (Figure 7). Unlike the established trend in most classes for reduction of species composition in the open seas, Prymnesiophyceae had a reverse trend of increasing the number of species towards the high seas. The maximum was at Galata in the 10-mile zone, intensely influenced by the impact of the Danube transformed waters. Only 10 miles off the coast were registered: Acanthoica acanthos Schiller, 1925, Amphora inflexa (Bréb.ex Kützing) Smith, 1873, Dinobryon balticum, Leptocylindrus danicus Cleve, 1889, Treubaria schmidlei (Schr.) Fott and Kov., 1975. Other phytoplankton species preferring offshore waters were: Amphidinium lacustre Stein, 1883 and
Phacus longicauda (Ehr.) Duj., 1841, observed only at Galata station, 20 miles off the coast.

With decreasing the intensity of light in depth, the number of phytoplankton species was also decreasing (Table 3). Only in depths of $10 \mathrm{~m}$ to the bottom were registered: Dinophysis acuminata $\mathrm{Cl}$. and Lachm., 1859, Gonyaulax orientalis Lind., 1924, Paralia sulcata (Ehr.) Cleve, 1873, Alexandrium monilatum (Howell) Balech, 1995, Chaetoceros danicus Cleve, 1889, Chaetoceros holsaticus Schütt, 1895, Diatoma tenuis Agardh, 1812, Protoperidinium bulla (Meun.) Balech, 1974, Phacus longicauda, Phaeocystis pouchetii (Har.) Lagerh., 1896, Thalassiosira nana Lohm., 1908 and Treubaria schmidlei.

Table 3. Taxonomic structure of phytoplankton (number of species by classes) by vertically, transect Galata, 2008-2016

\begin{tabular}{lrrr}
\hline \hline Class/Depth & $0 \mathrm{~m}$ & $10 \mathrm{~m}$ & under $10 \mathrm{~m}$ \\
\hline Dinophyceae & 64 & 50 & 38 \\
Bacillariophyceae & 43 & & 30 \\
Chrysophyceae & 1 & 4 & 4 \\
Cryptophyceae & 5 & 3 & 2 \\
Chlorophyceae & 7 & 1 & 1 \\
Chlorophyta incertae sedis & 1 & 1 & 1 \\
Craspedophyceae & 1 & 2 & 2 \\
Cyanophyceae & 5 & 2 & 2 \\
Dictyochophyceae & 1 & & 3 \\
Dinoflagellata incertae sedis & 1 & 5 & 2 \\
Euglenophyceae & 6 & 1 & 4 \\
Prasinophyceae & 2 & 5 & 9 \\
Prymnesiophyceae & 5 & 2 & 90 \\
Trebouxiophyceae & 2 & 109 & \\
Total number of species & 144 & & \\
\hline \hline
\end{tabular}


Table 4. List of phytoplankton species registered by transect Galata (2008-2016) (Legend: Dinophyceae - D.;

Bacillariophyceae - B.; Chrysophyceae - Chr.; Cryptophyceae - Cry.; Chlorophyceae - Chl.; Chlorophyta incertae sedis Chl.i.s.; Craspedophyceae - Cra.; Cyanophyceae - Cy.; Dictyochophyceae - Di.; Dinoflagellata incertae sedis - Din.i.s.; Euglenophyceae - E.; Prasinophyceae - P.; Prymnesiophyceae - Pry.; Trebouxiophyceae - Tr.)

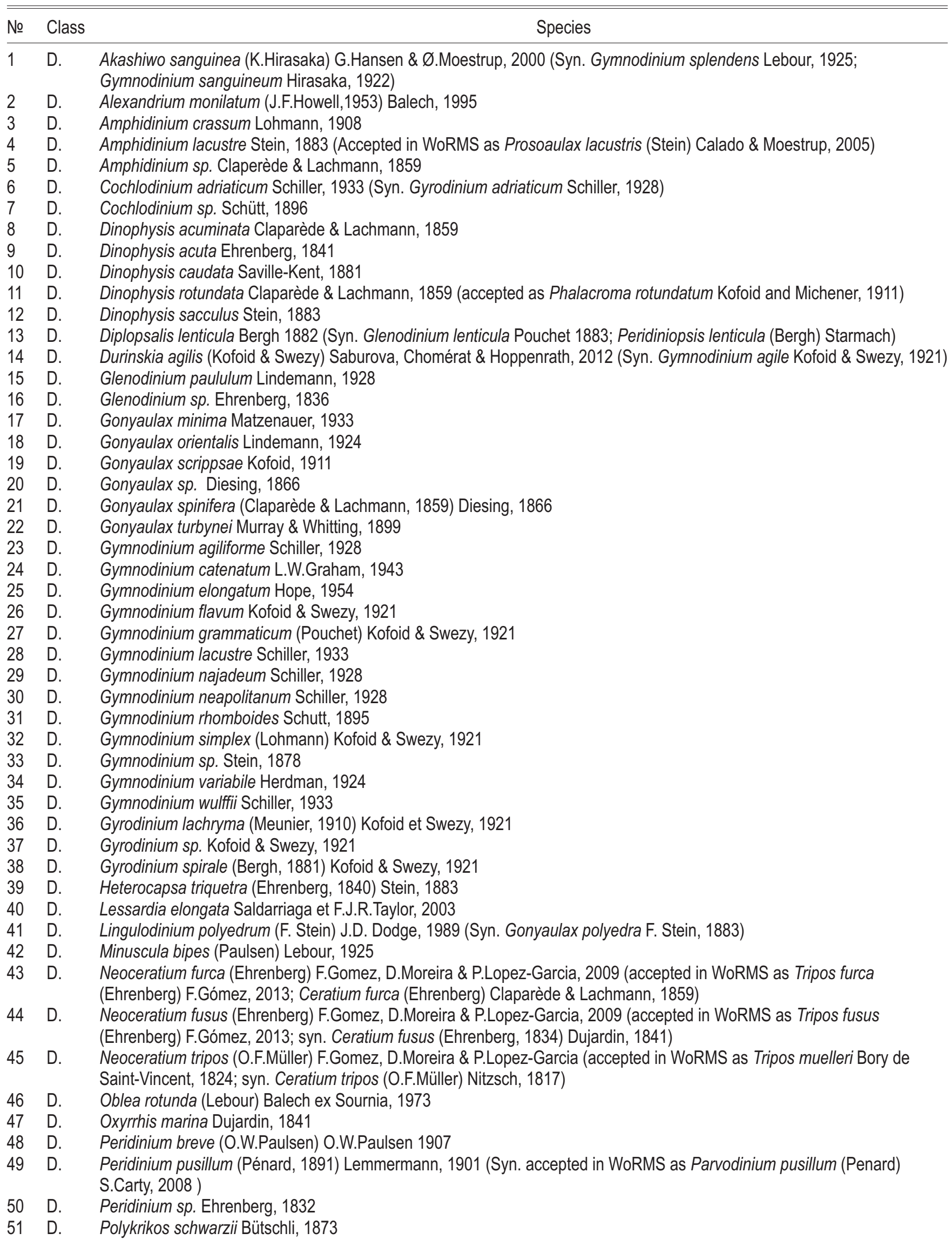


52 D. Pronoctiluca pelagica Fabre-Domergue, 1889

53 D. Prorocentrum compressum (Bailey, 1850) Abé ex Dodge, 1975

54 D. Prorocentrum cordatum (Ostenfeld, 1901) Dodge, 1975

55 D. Prorocentrum lima (Ehrenberg) F.Stein, 1878 (defined by us as Exuviaella caspica Kisselew, 1940)

56 D. Prorocentrum micans Ehrenberg, 1833

57 D. Prorocentrum scutellum Schröder, 1900

58 D. Protoceratium reticulatum (Claparède \& Lachmann, 1859) Bütschli, 1885

59 D. Protoperidinium brevipes (Paulsen, 1908) Balech, 1974

60 D. Protoperidinium bulla (Meunier, 1910) Balech, 1974

61 D. Protoperidinium conicum (Gran) Balech, 1974 (Syn. Peridinium conicum (Gran) Ostenfeld \& Schmidt, 1902)

62 D. Protoperidinium crassipes (Kofoid, 1907) Balech, 1974

63 D. Protoperidinium divergens (Ehrenberg, 1840) Balech, 1974

64 D. Protoperidinium granii (Ostenfield, 1906) Balech, 1974

65 D. Protoperidinium monovelum (Abé, 1936) Balech, 1974

66 D. Protoperidinium pellucidum Bergh, 1882

67 D. Protoperidinium steinii (Jørgensen, 1899) Balech, 1974

68 D. Protoperidinium thulesense (Balech, 1958) Balech, 1974 (Syn. Peridinium conicum f. islandica Braarud 1935)

69 D. Scrippsiella trochoidea (Stein, 1883) Balech ex Loeblich III, 1965

70 D. Woloszynskia pascheri (Suchlandt) von Stosch, 1973 (Syn. Gym. veris Lindemann, 1925; Gymnodinium hiemale Woloszynska, 1917)

71 B. Achnanthes longipes CAPEAgardh, 1824

72 B. Amphora inflexa (Brébisson ex Kützing) H.L. Smith, 1873

73 B. Amphora sp. Ehrenberg ex Kützing, 1844

74 B. Cerataulina pelagica (Cleve) Hendey, 1937 (syn. CAPE bergonii H.Perag.)

75 B. Chaetoceros affinis Lauder, 1864

76 B. Chaetoceros compressus Lauder, 1864

77 B. Chaetoceros curvisetus P.T. Cleve, 1889

78 B. Chaetoceros danicus Cleve, 1889

79 B. Chaetoceros holsaticus F.Schütt, 1895

80 B. Chaetoceros insignis Prosckina-Lavrenko, 1955

81 B. Chaetoceros lauderi Ralfs, 1864

82 B. Chaetoceros muelleri Lemmermann, 1898

83 B. Chaetoceros peruvianus Brightwell, 1856

84 B. Chaetoceros scabrosus Prosckina-Lavrenko

85 B. Chaetoceros septentrionalis Oestrup, 1895

86 B. Chaetoceros similis Cleve, 1896

87 B. Chaetoceros simplex Ostenfeld, 1901

88 B. Chaetoceros socialis H.S.Lauder, 1864

89 B. Chaetoceros sp. Ehrenberg, 1844

90 B. Cocconeis scutellum Ehrenberg, 1838

91 B Coscinodiscus granii Gough, 1905

92 B. Coscinodiscus sp. Ehrenberg, 1839

93 B. Cyclotella caspia Grunow, 1878

94 B. Cyclotella meneghiniana Kützing, 1844

95 B. Dactyliosolen fragilissimus (Bergon) Hasle in Hasle \& Syvertsen, 1996 (syn. Rhizosolenia fragilissima Bergon, 1903)

96 B. Diatoma tenuis CAPEA. Agardh, 1812 (Syn. Diatoma elongatum (Lyngb.) Ag., 1824)

97 B. Ditylum brightwellii (T.West) Grunow, 1885

98 B. Halamphora coffeaeformis (Agardh) Levkov, 2009 (Syn. Amphora coffeaeformis (CAPEAgardh) Kützing, 1844)

99 B. Leptocylindrus danicus P.T. Cleve, 1889

100 B. Leptocylindrus minimus Gran, 1915

101 B. Navicula sp. Bory de Saint-Vincent, 1822

102 B. Nitzschia closterium (Ehrenberg) W. Smith, 1853 (accepted in WoRMS as Cylindrotheca closterium (Ehrenberg) Reimann \& J.CAPELewin, 1964)

103 B. Nitzschia sp. Hassall, 1845

104 B. Nitzschia tenuirostris Mer., 1902

105 B. Paralia sulcata (Ehrenberg) P.T. Cleve, 1873 ( Syn. Melosira sulcata (Ehrenberg) Kützing, 1844)

106 B. Pleurosigma elongatum W. Smith, 1852

107 B. Proboscia alata (Brightwell) Sundström, 1986 (syn. Rhizosolenia alata Brightwell, 1858)

108 B. Pseudo-nitzschia delicatissima (P.T. Cleve, 1897) Heiden, 1928 (syn. Nitzschia delicatissima Cleve, 1897)

109 B. Pseudo-nitzschia seriata (P.T. Cleve, 1883) H. Peragallo in H. \& M. Peragallo, 1900 (syn. Nitzschia seriata P.T. Cleve, 1883)

110 B. Pseudosolenia calcar-avis (Schultze, 1858) Sundström, 1986 (syn. Rhizosolenia calcar-avis Schultze, 1858)

111 B. Skeletonema costatum (Greville) Cleve, 1873 
112 B. Skeletonema subsalsum (Cleve-Euler) Bethge, 1928

113 B. Synedra sp. Ehrenberg, 1830

114 B. Thalassionema nitzschioides (Grunow) Mereschkowsky, 1902

115 B. Thalassiosira anguste-lineata (A.Schmidt) G.Fryxell \& Hasle, 1977

116 B. Thalassiosira antiqua (Grunow) Cleve var. septata Pr.-Lavr., 1955 (syn. Accepted in AlgaeBase as Thalassiosira oestrupii (Ostenfeld) Hasle 1972)

117 B. Thalassiosira decipiens (Grunow) E.G.Jørgensen, 1905

118 B. Thalassiosira nana Lohmann, 1908

119 B. Thalassiosira parva Proshkina-Lavrenko, 1955

120 B. Thalassiosira rotula Meunier, 1910

121 Chr. Dinobryon balticum (Schütt) Lemmermann, 1900 (Syn. Dinobryon pellucidum Levander, 1894)

122 Cry. Chroomonas sp. Hansgirg, 1885

123 Cry. Cryptomonas sp. Ehrenberg, 1831

124 Cry. Leucocryptos marina (Braarud) Butcher, 1967 (syn. Bodo marina Braarud, 1935; Chilomonas marina (Braarud, 1935) Halldal, 1953)

125 Cry. Rhodomonas sp. Karsten, 1898

126 Cry. small Flagellates

127 Chl. Chlamydomonas sp. Ehrenberg, 1833

128 Chl. Chlorophyceae sp. Wille, 1884

129 Chl. Golenkinia radiata Chodat, 1894

130 Chl. Monoraphidium arcuatum (Korshikov) Hindák, 1970 (Syn. Ankistrodesmus arcuatus Korshikov)

131 Chl. Monoraphidium convolutum (Corda) Komárková-Legnerová, 1969 (Syn. Ankistrodesmus convolutus Corda, 1838)

132 Chl. Platymonas sp. G.S.West, 1916 (in WoRMS accepted as Tetraselmis sp. F.Stein, 1878)

133 Chl. Scenedesmus quadricauda (Turpin) Brébisson in Brébisson \& Godey 1835 (Syn. accepted in Algaebase is Desmodesmus quadricaudatus (Turpin) Hegewald)

134 Chl. Treubaria schmidlei (Schröder) Fott \& Kovácik, 1975 (Syn. Treubaria varia Tiffany \& Ahlstrom, 1931)

135 Chl.i.s. Poropila dubia Schiller, 1925

136 Cra. Bicosta spinifera (Throndsen) Leadbeater, 1978 (Salpingoeca spinifera Throndsen, 1970)

137 Cy. Cyanophyceae sp. Schaffner, 1909

138 Cy. Merismopedia sp. Meyen, 1839

139 Cy. Oscillatoria sp. Vaucher ex Gomont, 1892

140 Cy. Phormidium bulgaricum (Komárek) Anagnostidis \& Komárek 1988 (Syn. Oscillatoria bulgarica Komárek, 1956)

141 Cy. Spirulina sp. Turpin ex Gomont, 1892

142 Di. Apedinella radians (Lohmann) Campbell, 1973 (Syn. Apedinella spinifera (Throndsen) Throndsen, 1971)

143 Di. Distephanus speculum (Ehrenberg) Haeckel, 1887

144 Din.i.s. Hermesinum adriaticum O.Zacharias, 1906

145 E. Euglena viridis (O.F.Muller) Ehrenberg, 1832

146 E. Eutreptia lanowii Steuer, 1904

147 E. Eutreptia sp. Perty, 1852

148 E. Eutreptia viridis Perty, 1852

149 E. Eutreptiella sp. A.da Cunha, 1914

150 E. Phacus longicauda (Ehrenberg) Dujardin, 1841

151 E. Phacus sp. Dujardin, 1841

152 P. Pachysphaera sp. Ostenfeld, 1899

153 P. Pyramimonas sp. Schmarda, 1849

154 Pry. Acanthoica acanthos Schiller, 1925 (Syn. Accepted in WoRMS is Anacanthoica acanthos (Schiller) Deflandre, 1952)

155 Pry. Acanthoica quattrospina Lohmann, 1903

156 Pry. Coccolithus sp. E.H.L.Schwarz, 1894

157 Pry. Emiliania huxleyi (Lohmann) Hay \& Mohler, 1967

158 Pry. Phaeocystis pouchetii (M.P. Hariot, 1892) G. Lagerheim, 1896

159 Pry. Syracosphaera sp. Lohmann, 1902

160 Tr. Oocystis sp. Nägeli ex A.Braun, 1855

$161 \mathrm{Tr}$ Trochiscia multispinosa (Möbius) Lemmermann

\section{Conclusion}

In Black Sea marine area, along transect Galata (1-20 nautical miles, 2008-2016) was established high species diversity: 161 species, 84 genera, 62 families, 14 classes and 7 phyla. For most of the year of investigation the taxonomic composition was dominated by class Dinophyceae (25.93-54.17\%) with most species in the period from April to August. Class Bacillariophyceae (22.06-43.33\%) participated with a higher share in taxonomy from September to March. The diatoms dominated only in October and December. While the total number of phytoplankton species decreased with distance from shore, the percentage of peridineas and diatoms in phytoplankton total taxonomic composition grew. Increased biodiversity was observed only in class Prymnesiophyceae in the open sea. 


\section{References}

Christensen T, 1966. Alger. In: Botanik (ed. T.W. Böcher, M. Lange and T. Sørensen), 2 Systematisk Botanik, vol. 2, 1-180, Copenhagen-Munksgaard (De).

Dineva S, 2009. Impact assessment of climate change on the Varna Bay. Proceedings of the Institute of Fish Resources - Varna (IFR), 27, pp. 7-10.

Dineva S, 2013. Regional-Level Impacts of Climate Change on the Black Sea. In: Proceedings of Global Congress on Integrated Coastal Management: Lessons Learned to Address New Challenges EMECS 10 - MEDCOAST 2013 (ed. E. Özhan), vol.1, 635-644, MEDCOAST, 30 October - 03 November, 2013, Marmaris, Turkey.

Glezer ZI, Zhuze AP, Makarova IV, Proshkina-Lavrenko Al and Sheshukova-Poretskaya VS, 1974. Diatom algae of the USSR, Fossil and modern, Practical guidance. Volume 1, Responsible editor: A.I. Proshkina-Lavrenko, Nauka Publishers, Leningrad (Ru). Hibberd DJ, 1975. Observations on the ultrastructure of the choanoflagellate Codosiga botrytis (Ehr.) Saville-Kent with special reference to the flagellar apparatus. Journal of Cell Science, 7, 191219.

Kiselev IA, 1950. The armored flagellates (Dinoflagellata) of the seas and fresh waters of the USSR. Determinants of the USSR fauna. Published by the Zoological Institute of the USSRAcademy of Sciences (Ru).

Klisarova D, Gerdzhikov D, Kostadinova G and Petkov G, 2015a. Investigation of phytoplankton in the Varna bay (2005-2014). In: Proceedings of the Twelfth International Conference on the Mediterranean Coastal Environment MEDCOAST 2015 (ed. E. Özhan), 299-308, MEDCOAST, 06-10 October 2015, Varna, Bulgaria.

Klisarova D, Petrova E, Gerdzhikov D and Stoikov S., 2015b. State of the marine communities in the Burgas bay. In: Proceedings of the Twelfth International Conference on the Mediterranean Coastal Environment MEDCOAST 2015, (ed. E. Özhan), 283-292, MEDCOAST, 06-10 October 2015, Varna, Bulgaria.

Lebour MV, 1925. The Dinoflagellates of Northern seas. Marine Biological association of the United Kingdom, Plymouth.

Moncheva S and Parr B, 2010. Manual for Phytoplankton Sampling and Analysis in the Black Sea, 68, from http://documents.blackseacommission.org/Downloads/ Phytoplankton_\%20Mannual-Final1.pdf (6, November, 2010 date last accessed).

Moncheva S, 2010. An updated and WoRMS revised phytoplankton checklist from studies in Bulgarian Black Sea area - a contribution to Black Sea phytoplankton check-list, from http://phyto.bss.ibss. org.ua/wiki/List_checked (12, July, 2010 date last accessed).

Moncheva S and Slabakova V, 2013. The predominant types of habitats in the water column, II.2.2. In: Initial assessment of the status of the marine environment, according to art. 8 of the MSFD and OEPMW, Report of (IO-BAS), under contract № 203/ 09.08.2012 between BDBSR and IO-BAS, pp. 165 - 167 (Bg).

Moncheva S, Slabakova V and Doncheva V, 2013. Phytoplankton, II.2.2.1. In: Initial assessment of the status of the marine environment, according to art. 8 of the MSFD and OEPMW ", Report of (IO-BAS), under contract № 203 / 09.08.2012 between BDBSR and IO-BAS, $168-180(\mathrm{Bg})$

Morozova-Vodyanitskaya NV, 1954. Phytoplankton of the Black Sea, Part II. Proceedings of the Sevastopol Biological Station, 8, 1199 (Ru).

Nesterova D, Moncheva S, Mikaelyan A, Vershinin A, Akatov V,
Boicenco L, Aktan Y, Sahin F and Gvarishvili T, 2008. The state of phytoplankton, Chapter 5. In: State of the Environment of the Black Sea (2001-2006/7). Black Sea Commission Publications 2008-3, Istanbul, Turkey.

Nordisches Plankton, 1908. Botanischer Teil. (eds. Prof. K.Brandt und Prof. Apstein) Kiel, Verlag von Lipsius \&Tischer, Kiel und Leipzig (De).

Petrova-Karadjova V, 1973. Dynamics of the biomass of the phytoplankton in the Black Sea off the Bulgarian coast during the period of 1964-1970. Proceedings of the Research Institute of Fisheries and Oceanography, Varna, 12, pp. 41-66 (Bg).

Petrova V, 1963. Phytoplankton along the Bulgarian coast of the Black Sea during the period 1954-1957. Proceedings of the Central Research Institute of Fish and Fisheries, Varna,3, pp. 31-60 (Bg).

Petrova V, 1964. Phytoplankton in the Black Sea in front of the Bulgarian coast during the period 1958-1960. Proceedings of the Institute of fisheries and fishing, Varna, pp. 5-32 (Bg).

Petrova V, 1965. Features in the development of phytoplankton in the Bulgarian Black Sea coast in 1961-1963. Proceedings of the Research Institute of Fisheries and Oceanography, Varna, 6, pp. 63$74(\mathrm{Bg})$.

Petrova V, 1966. The phytoplankton in the coastal areas of the western half of the Black Sea in 1958-1960. Proceedings of the Research Institute of Fisheries and Oceanography, Varna, 7, pp. 29$43(\mathrm{Bg})$.

Petrova-Karadjova V and Moncheva S, 1998. Phytoplankton. In: Konsulov, A. (ed.), National Report of Bulgarian Black Sea area, GEF Black Sea Environment Ser., 5, pp. 52-58 (Bg).

Petrova D and Gerdzhikov D, 2012. Development of phytoplankton in the aquatories in front of cape Galata (2010-2011). Proceedings of the Union of Scientists - Varna, Maritime Science Series, pp. 52-57 (Bg).

Petrova D and Gerdzhikov D, 2015. Phytoplankton taxonomy in the Bulgarian coastal waters (2008 - 2013). Bulgarian Journal of Agricultural Science, 21 (Supplement 1), pp. 90-99.

Polishchuk LV, 1999. Contribution analysis of disturbance - caused changes in phytoplankton diversity. Ecology, 80, 721-5.

Proshkina-Lavrenko Al, 1955. Diatom algae of the plankton of the Black Sea. Publisher Academy of Sciences of the USSR, MoscowLeningrad (Ru).

Proshkina-Lavrenko Al, 1959. Modern and fossil silicoflagellates and ebriides of the Black Sea basin. Proceedings Bin USSR Academy of Sciences, 11, 142-175(Ru).

Proshkina-Lavrenko Al, 1963. Diatom algae of the benthos of the Black Sea. Publisher Academy of Sciences of the USSR, MoscowLeningrad (Ru)

Rabenhorsts L, 1930. Flagellatae. In: Kryptogamen - Flora von Deutschland, 10, Abt. 2-3, Akad. Verlag., Leipzig, Oesterreich und der Schweiz (De).

Reynolds CS, 2006. The Ecology of Phytoplankton. Cambridge University Press, New York.

Schiller J, 1931-1937. Dinoflagellatae (Peridinineae) in monographischer Behandlung. In: Kryptogamen-Flora von Deutschland (ed. L.Rabenhorst), Vol. 10 (3): Teil 1 (1-3) (1931-1933): Teil 2 (1-4) (1935-1937), Akad. Verlag, Leipzig, Österreichs und der Schweiz (De).

Sommer U, 1995. An experimental test of the intermediate disturbance hypothesis using cultures of marine phytoplankton. Limnology and Oceanography, 40, 1271-1277.

Sommer U, Padis'ak J, Reynolds CS and Juh'asz-Nagy P, 1993. Hutchinson's heritage: the diversity-disturbance relationship in 
phytoplankton. Hydrobiologia, 249, 1-7.

Temniskova D, Kirjakov I, Moncheva S, Stoyneva M, Mladenov R, Belkinova D, Stancheva R and Ivanov P, 2005. Biodiversity of algae in Bulgaria. In: Petrova, A. (ed.), Contemporary state of biodiversity in Bulgaria - problems and perspectives, Bulgarian Biodiversity Platform, Sofia, 11-36 (Bg).

Temnskova DN and Stoyneva MP, 2011. Algology. Vol. I and II, Pensoft, Sofia $(\mathrm{Bg})$.

Vodenicharov D, Draganov S and Temniskova D, 1971. Flora of Bulgaria -Algae, People's Education, Sofia (Bg).

WoRMS, 2016. World Register of Marine Species, from http://www.marinespecies. org/index.php (23 Nov, 2016, date last accessed).

Zabelina MM, Kiselev IA, Proshkina - Lavrenko Al and
Sheshukova VS, 1950. Diatom analysis, The determinant of fossil and modern diatom algae, Order of the Pennales. Book 3, (eds. A.I. Proshkina Lavrenko and A.N. Krishtofovicha) State Publishing House of Geological Literature, Moscow - Leningrad (Ru).

Zhuze AP, Proshkina-Lavrenko Al and Sheshukova VS, 1949a. Diatom analysis. Book 1, (ed. A.I. Proshkina-Lavrenko) State Publishing House of Geological Literature, Moscow - Leningrad (Ru).

Zhuze LP, Kiselev IA, Poretsky VS, Proshkina-Lavrenko Al and Sheshukova VS, 1949b. Diatom analysis, The determinant of fossil and modern diatom algae, Order Centrales and Mediales. Book 2 (eds. A.I. Proshkina-Lavrenko and A.N. Krishtofovich. State Publishing House of Geological Literature, Moscow - Leningrad (Ru). 


\section{Genetics and Breeding}

Variation in the agronomic and morphological traits in spring barley

N. Dyulgerov, B. Dyulgerova

Study on the loss of accuracy of AC method for milk yield control in sheep

D. Dimov, P. Zhelyazkova, A. Vuchkov

Hordein polymorphism between spring barley cultivars by SDS-PAGE electrophoresis

N. Neykov, S. Doneva

\section{Nutrition and Physiology}

Comparative study of rapeseed, monofloral types and multifloral honey by some physico-chemical parameters

I. Zhelyazkova, S. Lazarov

Body condition score, nonesterified fatty acids and beta-hydroxybutyrate concentrations in goats with subclinical ketosis

V. Marutsova, R. Binev

\section{Production Systems}

Lucrative status of improved dual purpose cowpea (Vigna unguiculata L., Walp) in Damboa, Borno State, North-Eastern Nigeria

B.H. Gabdo

Study on the emptying time of grain harvester hoppers

K. Trendafilov, N. Delchev, B. Kolev, G. Tihanov

Length of the growing season and yield in Triticum monococcum L., in accordance with the growing conditions

S. Stamatov, E. Valchinova, G. Desheva, K. Uzundzhalieva, P. Chavdarov, T. Cholakov, B. Kyosev, R.

Ruseva, N. Velcheva

Productivity of durum wheat cultivar Predel at nitrogen-phosphorous fertilization

L. Plescuta

Effect of the herbicide treatment dose on the weed infestation in common winter wheat

Z. Petrova

Evaluation of some technological properties of Caucasian ram wool

D. Pamukova, G. Staykova, N. Stancheva, D. Panayotov 


\section{Agriculture and Environment}

Saved $\mathrm{CO}_{2}$ emissions by using renewable sources for hot water yield in Bulgarian dairy farms

R. Georgiev, R. Slavov, K. Peychev, D. Georgiev, S. Apostolov, J. Ellingsen, J. Tønnesen

Inventory of the legal base for reclamation of lands disturbed by open-cast mining in Bulgaria

M. Banov, V. Tzolova, I. Kirilov

Taxonomic composition of phytoplankton in Black Sea area in front of the Cape Galata (2008-2016)

D. Klisarova, D. Gerdzhikov

Biodiversity of the macrozoobenthos in some protected marine areas along Bulgarian Black Sea coast

E. Petrova, S. Stoykov

Heavy metals in organs of gudgeon (Gobio gobio L.) from Vardar River, R. Macedonia

R. Nastova, V. Kostov, I. Uslinovska

Product Quality and Safety

Mathematical methods for assessment and analysis of honey yield data for Bulgaria and the

N. Keranova

Carcass traits and meat quality of different slow growing and fast growing broiler chickens

M. Oblakova, N. Mincheva, P. Hristakieva, I. Ivanova, M. Lalev, Sv. Georgieva

Role and importance of the awareness for whey in dairy sector at an international level 


\section{Instruction for authors}

\section{Preparation of papers}

Papers shall be submitted at the editorial office typed on standard typing pages (A4, 30 lines per page, 62 characters per line). The editors recommend up to 15 pages for full research paper ( including abstract references, tables, figures and other appendices)

The manuscript should be structured as follows: Title, Names of authors and affiliation address, Abstract, List of keywords, Introduction, Material and methods, Results, Discussion, Conclusion, Acknowledgements (if any), References, Tables, Figures.

The title needs to be as concise and informative about the nature of research. It should be written with small letter /bold, 14/ without any abbreviations.

Names and affiliation of authors The names of the authors should be presented from the initials of first names followed by the family names. The complete address and name of the institution should be stated next. The affiliation of authors are designated by different signs. For the author who is going to be corresponding by the editorial board and readers, an E-mail address and telephone number should be presented as footnote on the first page. Corresponding author is indicated with *

Abstract should be not more than 350 words. It should be clearly stated what new findings have been made in the course of research. Abbreviations and references to authors are inadmissible in the summary. It should be understandable without having read the paper and should be in one paragraph.

Keywords: Up to maximum of 5 keywords should be selected not repeating the title but giving the essence of study.

The introduction must answer the following questions: What is known and what is new on the studied issue? What necessitated the research problem, described in the paper? What is your hypothesis and goal?

Material and methods: The objects of research, organization of experiments, chemical analyses, statistical and other methods and conditions applied for the experiments should be described in detail. A criterion of sufficient information is to be possible for others to repeat the experiment in order to verify results.

Results are presented in understandable tables and figures, accompanied by the statistical parameters needed for the evaluation. Data from tables and figures should not be repeated in the text. Tables should be as simple and as few as possible. Each table should have its own explanatory title and to be typed on a separate page. They should be outside the main body of the text and an indication should be given where it should be inserted.

Figures should be sharp with good contrast and rendition. Graphic materials should be preferred. Photographs to be appropriate for printing. Illustrations are supplied in colour as an exception after special agreement with the editorial board and possible payment of extra costs. The figures are to be each in a single file and their location should be given within the text.

Discussion: The objective of this section is to indicate the scientific significance of the study. By comparing the results and conclusions of other scientists the contribution of the study for expanding or modifying existing knowledge is pointed out clearly and convincingly to the reader. Conclusion: The most important consequences for the science and practice resulting from the conducted research should be summarized in a few sentences. The conclusions shouldn't be numbered and no new paragraphs be used. Contributions are the core of conclusions. References:

In the text, references should be cited as follows: single author: Sandberg (2002); two authors: Andersson and Georges (2004); more than two authors: Andersson et al.(2003). When several references are cited simultaneously, they should be ranked by chronological order e.g.: (Sandberg, 2002; Andersson et al., 2003; Andersson and Georges, 2004).

References are arranged alphabetically by the name of the first author. If an author is cited more than once, first his individual publications are given ranked by year, then come publications with one co-author, two co-authors, etc. The names of authors, article and journal titles in the Cyrillic or alphabet different from Latin, should be transliterated into Latin and article titles should be translated into English. The original language of articles and books translated into English is indicated in parenthesis after the bibliographic reference $($ Bulgarian $=\mathrm{Bg}$, Russian $=\mathrm{Ru}$, Serbian $=\mathrm{Sr}$, if in the Cyrillic, Mongolian =
Mo, Greek = Gr, Georgian = Geor., Japanese $=\mathrm{Ja}$, Chinese $=\mathrm{Ch}$, Arabic $=\mathrm{Ar}$, etc.)

The following order in the reference list is recommended:

Journal articles: Author(s) surname and initials, year. Title. Full title of the journal, volume, pages. Example:

Simm G, Lewis RM, Grundy B and Dingwall WS, 2002. Responses to selection for lean growth in sheep. Animal Science, 74, 39-50

Books: Author(s) surname and initials, year. Title. Edition, name of publisher, place of publication. Example:

Oldenbroek JK, 1999. Genebanks and the conservation of farm animal genetic resources, Second edition. DLO Institute for Animal Science and Health, Netherlands.

Book chapter or conference proceedings: Author(s) surname and initials, year. Title. In: Title of the book or of the proceedings followed by the editor(s), volume, pages. Name of publisher, place of publication. Example:

Mauff G, Pulverer G, Operkuch W, Hummel K and Hidden C, 1995. C3variants and diverse phenotypes of unconverted and converted C3. In: Provides of the Biological Fluids (ed. $\mathrm{H}$. Peters), vol. 22, 143-165, Pergamon Press. Oxford, UK.

Todorov N and Mitev J, 1995. Effect of level of feeding during dry period, and body condition score on reproductive performance in dairy cows, IX $X^{\text {th }}$ International Conference on Production Diseases in Farm Animals, September 11-14, Berlin, Germany.

Thesis:

Hristova D, 2013. Investigation on genetic diversity in local sheep breeds using DNA markers. Thesis for PhD, Trakia University, Stara Zagora, Bulgaria, (Bg).

The Editorial Board of the Journal is not responsible for incorrect quotes of reference sources and the relevant violations of copyrights.

\section{Animal welfare}

Studies performed on experimental animals should be carried out according to internationally recognized guidelines for animal welfare. That should be clearly described in the respective section "Material and methods". 


\section{AGRICULTURAL \\ SCIENCE AND TECHNOLOGY}

Volume 9, Number 4 December 2017
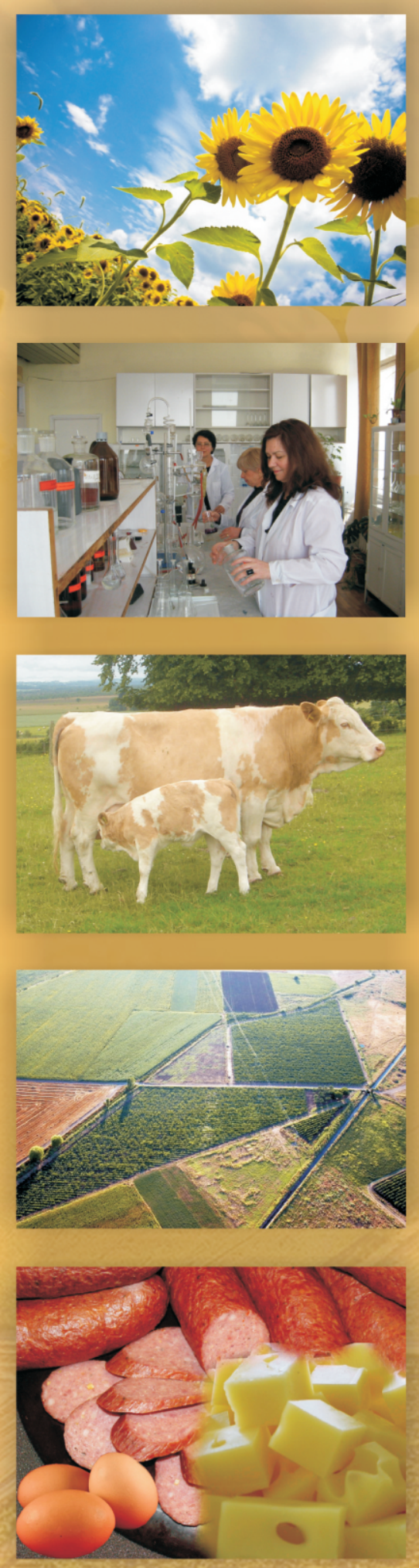

Journal web site: 